\title{
AC 2008-2652: ACADEMIC ACHIEVEMENT AND RETENTION IN A MINORITY ENGINEERING PROGRAM
}

\section{Mary Anderson-Rowland, Arizona State University}

MARY R. ANDERSON-ROWLAND, PhD, is the PI of three academic scholarship programs and a fourth program for transfer students. An Associate Professor in Industrial Engineering at Arizona State University, she was the Associate Dean of Student Affairs in the Ira A. Fulton School of Engineering at Arizona State University from 1993-2004. She received the ASEE Minorities Award 2006, the SHPE Educator of the Year 2005, and won the Narional Engineering Award in 2003, the highest honor given by AAES. In 2002 she was named the Distinguished Engineering Educator by the Society of Women Engineers. Her awards are based on her mentoring of students, especially women and underrepresented minority students, and her research in the areas of recruitment and retention. A SWE and ASEE Fellow, she is the PIC IV Chair and a frequent speaker on career opportunities in engineering, especially for women and minority students.

\section{Callie Ruben, Arizona State University}

Callie Rubin is a Senior in Aerospace Engineering at Arizona State University. She is an active member of the Society of Hispanic Professional Engineers and the Society of Women Engineers. Callie was the Assistant Program Coordinator for Engineering Diversity Programs and the Summer Minority Engineering Program during 2007. 


\title{
Academic Achievement and Retention in a Minority Engineering Program
}

\begin{abstract}
The Ira A. Fulton School of Engineering at Arizona State University (ASU) was awarded funding in 2003 as a part of 13 five-year block grants given to colleges and universities that year. The funding was given by the National Action Council for Minorities in Engineering (NACME) for a program to increase the number of underrepresented minority students (African American, Hispanic, and Native American) enrolled in engineering and to increase their retention and graduation rates to that comparable for non-minority students.
\end{abstract}

This successful NACME program at ASU has now completed four years of programming and has now had 73 students who have held NACME Scholarships. This paper looks at the NACME program lessons learned, the retention of the NACME cohorts relative to non-minority students and to minority students who did not attend the NACME program, the academic achievement of the students, and areas of the program which could improve. The paper includes the summary of the semester evaluations submitted by the students.

\section{Introduction and Background}

In 2003, the National Action Council for Minorities in Engineering (NACME) gave 13 five-year block grants to colleges and universities. Arizona State University (ASU) was one of those 13 schools. The purpose of the funding was to increase the number of underrepresented minority students (African American, Hispanic, and Native American) enrolled in engineering and to increase their retention and graduation rates to that comparable for non-minority students. An additional goal of the ASU Ira A. Fulton School of Engineering NACME Program is to have the NACME students go on to graduate school.

There have been many targeted efforts to increase the recruitment and retention of underrepresented minority engineering students. ${ }^{1}$ Effective retention models for minority freshmen include: summer bridge programs, ${ }^{2}$ year-long bridge programs, ${ }^{3}$ minority engineering programs,${ }^{4,5}$ and academic scholarship programs ${ }^{6}$. The NACME program at ASU builds on a summer bridge program and incorporates the other three types of programs just mentioned. ${ }^{7}$

Each summer the Ira A. Fulton School of Engineering runs a two-week residential Minority Engineering (MEP) Bridge Program to interest, encourage, and support minority students just graduated from high school who are thinking about engineering. Nearly $100 \%$ of the students who attend the summer bridge program attend ASU in the fall as engineering or computer science students. The School of Engineering includes both Computer Science Engineering and Computer Science in the same department. Henceforth in this paper when engineering is mentioned, it includes engineering and computer science students. Students from this MEP program, as well as all entering minority engineering students, are sent emails to urge them to apply for the NACME scholarship if they qualify. With admission data in hand, emails are just sent to students with at least a 3.0 GPA in high school. 
The NACME scholarship is advertised on the School's website. All School of Engineering students, including new students, receive an email from the School's scholarship office encouraging students to apply for a scholarship. A general scholarship application applies for all scholarships and students must then indicate for which scholarships they wish to be considered. The general scholarship application form asks for demographics and a statement of purpose. Individual scholarships may require additional materials for the application. The NACME scholarship further requires two letters of recommendation, at least one from an instructor.

The basic qualifications to become a NACME scholar are:

- Enrolled full-time in engineering or computer science

- Have at least a 3.0 GPA

- Have financial need as shown by the FAFSA

- U.S. citizen/permanent resident

The amount of the scholarship is up to $\$ 2,500$ depending of the amount of unmet financial need of the student. To be continued in the program the student needs to be enrolled full-time, complete at least 24 hours per academic year, attend the NACME meetings, complete all of the NACME assignments, and continue to have unmet financial need. The scholarships are awarded for a year, with a review of eligibility each semester. To renew, the student must complete a scholarship application, but letters of recommendation are no longer required.

The NACME program is intended for underrepresented minority students and the NACME grant can only be used for underrepresented minority students. The first year of the program, all 21 NACME scholars were underrepresented minority students. After discussions with the University's Legal Counsel, beginning the second year both minority and non-minority students are admitted to the program. ${ }^{8}$ The selection process is difficult, but NACME funds support minority students and the School of Engineering funds non-minority students. The scholarship advertisement on the web is open to all students. With the special efforts made to encourage minority students to apply, the program remains predominantly underrepresented minority.

The NACME Program is based on the belief that just giving a scholarship to a student with unmet financial need is not enough to retain and to graduate a student in engineering. During the first freshmen semester, the NACME students are required to enroll in a two-hour Academic Success class. This class has been detailed in other papers ${ }^{9-15}$ and includes the 4.0 Plan system for learning ${ }^{16}$; a textbook on survival in engineering ${ }^{17}$; video tapes ${ }^{18}$; representatives from Career Services and an engineering student research program, individual student presentations; a visit by officers of AISES, NSBE, SHPE, and SWE; and a group project with report and presentations. During the second freshmen semester, the NACME students meet for an hour eight times during the semester. Topics include resumes, School and University resources, engineering in industry, consulting, and graduate school. Two particular helps for empowering the students were developed: a Check List for the detailed time management schedule ${ }^{10}$ and a Check List for an effective resume. ${ }^{14}$

At the beginning of the first semester the freshmen students are given instructions on how their assignments and extra curricular events (such as attending an AISES, SHPE, NSBE, or SWE meetings) can earn them points in the course. Since extra credit points can be earned, any student with the will can earn an $\mathrm{A}$ in the course by doing the required assignments. 
From the sophomore year on, NACME students meet six times a semester for a 50-minute meeting. The students meet in a well furnished conference room and are served refreshments after the first semester to help make them fell special. Each semester begins with a review of the 4.0 Plan ${ }^{16}$ (developed by Donna O. Johnson) and a discussion by the students on the Plan including what works especially well and a new resolve to stick with the plan the whole next semester. Students often reveal that their GPA for the semester is a direct reflection of how well they stayed with the 4.0 Plan. Speakers are brought in from academia, career services, and all areas of engineering including consulting, working with drug testing equipment, medical related industries, transportation, and semiconductor industries. The favorite programs are the graduate student panels and engineers (usually with a graduate degree) from industry talk about their work and how their advanced degrees helped them to have challenging and interesting careers.

Usually there are a few openings in the NACME program to bring in sophomores and juniors. Unfortunately there is always some attrition in addition to graduation. The attrition is usually due to the student deciding that a major other than engineering looks more attractive. However, this decision usually occurs after the student has had difficulty with the mathematic classes. ${ }^{6}$ In addition, after students have been in the NACME program for several years, they may be put into another academic scholarship program sponsored by the National Science Foundation for juniors and seniors. The advantage of this second program is that its stipend is now $\$ 4,000$ for the academic year and is composed of juniors, seniors, and graduate students. ${ }^{19}$ Networking with these advanced students is a good experience for the NACME students.

\section{Retention}

The goal of the NACME program is to have underrepresented minority students in engineering and computer science retained and graduated at the same rate as non-minority students. Also expected is that the NACME program is having a positive effect on the students and the retention of the NACME students would be higher than minority students who were not NACME students. This successful NACME program at ASU has completed four years of programming and has now had 75 students who have held NACME scholarships. To date, the NACME students are persisting at the same rate or better than non-minority engineering students and minority engineering students not in the NACME program.

Although the NACME program seemed successful for the first year and a half, evaluations from the students clearly showed that they did not believe that the NACME program was actually helping them with their academics. As a response to this and after reading the just printed "Guaranteed 4.0", , beginning in Spring 2003, the NACME director presented the 4.0 Plan learning system at the beginning of each semester to NACME students. One dramatic example of the impact of this system is that one freshman student earned over a 3.9 GPA after learning of the 4.0 Plan even though he had only earned a 2.42 GPA his first semester. Unfortunately, learning about the 4.0 Plan is not a cure-all. In order for students to become and to remain successful, they must continuously commit themselves to being a full-time student and to a time management plan that includes the steps necessary to earn a 4.0 GPA. In the experience of this director, the six main influences that can destroy a student's capability to be a good student are: addictions to alcohol, drugs, or chat rooms; family problems; over involvement in student organizations; and romantic relationships. 
The retention results are shown in the following Tables I-V. We can see that the NACME program has been successful in graduating and retaining engineering students at the same or higher rate than that for non-minority students. The positive effect of the NACME program on minority students is clearly seen by the higher retention rate of NACME students than other minority students not in the NACME program. The overall retention rates in engineering are certainly not where they should be. In the past few years, the general admission standard has been raised from graduation in the top $50 \%$ of the high school class to the top $25 \%$ of the class. Additionally, many of the original engineering students are still enrolled at ASU; however they are now enrolled in non-engineering majors. For example, of the 21 students in the first NACME class, 10 are still enrolled in engineering, 6 are still enrolled at ASU in non-engineering majors. Of the 5 that are no longer enrolled at ASU, at least one student, who transferred in engineering to a school close to home, is still enrolled and is now in a non-engineering major. This means that $76.2 \%$ of the first NACME class are still enrolled at or have graduated from ASU and this retention rate is also better than the retention rate of engineering minority students not in the NACME program (56.4\%) and of non-minority engineering students (69\%). Table VI shows these results.

\begin{tabular}{|l|l|l|l|l|l|l|}
\hline & \multicolumn{5}{|c|}{ Enrollment Period } & \\
\hline $\begin{array}{l}\text { 2003-2004 Cohort } \\
\text { First-time, Full- } \\
\text { time Students }\end{array}$ & $\begin{array}{l}\text { Fall } \\
\mathbf{2 0 0 3 - 2 0 0 4}\end{array}$ & $\begin{array}{l}\text { Fall } \\
\mathbf{2 0 0 4 - 2 0 0 5}\end{array}$ & $\begin{array}{l}\text { Fall } \\
\mathbf{2 0 0 5 - 2 0 0 6}\end{array}$ & $\begin{array}{l}\text { Fall } \\
\mathbf{2 0 0 6 - 2 0 0 7}\end{array}$ & $\begin{array}{l}\text { Fall } \\
\mathbf{2 0 0 7 - 2 0 0 8}\end{array}$ & $\begin{array}{l}\text { Retention } \\
\%\end{array}$ \\
\hline $\begin{array}{l}\text { Block Grant } \\
\text { NACME Scholars } \\
\text { Total Number }\end{array}$ & 21 & 15 & 13 & 12 & 10 & $47.6 \%$ \\
\hline $\begin{array}{l}\text { Minority Students } \\
\text { (excluding } \\
\text { NACME scholars) } \\
\text { Total Number }\end{array}$ & 147 & 89 & 57 & 48 & 40 & $27.2 \%$ \\
\hline $\begin{array}{l}\text { Non-Minority } \\
\text { Students } \\
\text { Total Number }\end{array}$ & 591 & 393 & 279 & 256 & 241 & $40.8 \%$ \\
\hline
\end{tabular}

Table I. Fall 2003-2004 Cohort by Enrollment Periods and Percent Retention in Engineering

*Enrollment numbers include students graduated in engineering or still enrolled in engineering.

\begin{tabular}{|l|l|l|l|l|l|}
\hline & \multicolumn{4}{|c|}{ Enrollment Period } & \\
\hline $\begin{array}{l}\text { 2004-2005 Cohort } \\
\text { First-time, Full- } \\
\text { time Students }\end{array}$ & $\begin{array}{l}\text { Fall } \\
\mathbf{2 0 0 4 - 2 0 0 5}\end{array}$ & $\begin{array}{l}\text { Fall } \\
\mathbf{2 0 0 5 - 2 0 0 6}\end{array}$ & $\begin{array}{l}\text { Fall } \\
\mathbf{2 0 0 6 - 2 0 0 7}\end{array}$ & $\begin{array}{l}\text { Fall } \\
\mathbf{2 0 0 7 - 2 0 0 8}\end{array}$ & $\begin{array}{l}\text { Retention } \\
\%\end{array}$ \\
\hline $\begin{array}{l}\text { Block Grant } \\
\text { NACME Scholars } \\
\text { Total Number }\end{array}$ & 11 & 10 & 9 & 8 & $72.7 \%$ \\
\hline $\begin{array}{l}\text { Minority Students } \\
\text { (excluding } \\
\text { NACME scholars) } \\
\text { Total Number }\end{array}$ & 125 & 75 & 51 & 42 & $33.6 \%$ \\
\hline $\begin{array}{l}\text { Non-Minority } \\
\text { Students } \\
\text { Total Number }\end{array}$ & 600 & 415 & 314 & 279 & $46.5 \% \%$ \\
\hline
\end{tabular}

Table II. 2004-2005 Cohort by Enrollment Periods and Percent Retention in Engineering 


\begin{tabular}{|l|l|l|l|l|}
\hline & \multicolumn{3}{|c|}{ Enrollment Periods } & \\
\hline $\begin{array}{l}\text { 2005-2006 Cohort } \\
\text { First-time, Full- } \\
\text { time Students }\end{array}$ & $\begin{array}{l}\text { Fall } \\
\mathbf{2 0 0 5 - 2 0 0 6}\end{array}$ & $\begin{array}{l}\text { Fall } \\
\mathbf{2 0 0 6 - 2 0 0 7}\end{array}$ & $\begin{array}{l}\text { Fall } \\
\mathbf{2 0 0 7 - 2 0 0 8}\end{array}$ & $\begin{array}{l}\text { Retention } \\
\%\end{array}$ \\
\hline $\begin{array}{l}\text { Block Grant } \\
\text { NACME Scholars } \\
\text { Total Number }\end{array}$ & 10 & 8 & 7 & $70 \%$ \\
\hline $\begin{array}{l}\text { Minority Students } \\
\text { (excluding } \\
\text { NACME scholars) } \\
\text { Total Number }\end{array}$ & 165 & 100 & 71 & $43 \%$ \\
\hline $\begin{array}{l}\text { Non-Minority } \\
\text { Students } \\
\text { Total Number }\end{array}$ & 594 & 415 & 307 & $51.7 \%$ \\
\hline
\end{tabular}

Table III. 2005-2006 Cohort by Enrollment Periods and Percent Retention in Engineering

\begin{tabular}{|l|c|c|c|}
\hline & \multicolumn{2}{|c|}{ Enrollment Periods } & \\
\hline $\begin{array}{l}\text { 2006-2007 Cohort } \\
\text { First-time, Full- } \\
\text { time Students }\end{array}$ & $\begin{array}{l}\text { Fall } \\
\text { 2006-2007 }\end{array}$ & $\begin{array}{l}\text { Fall } \\
\mathbf{2 0 0 7 - 2 0 0 8}\end{array}$ & $\begin{array}{l}\text { Retention } \\
\%\end{array}$ \\
\hline $\begin{array}{l}\text { Block Grant } \\
\text { NACME Scholars } \\
\text { Total Number }\end{array}$ & 8 & 7 & $87.5 \%$ \\
\hline $\begin{array}{l}\text { Minority Students } \\
\text { (excluding NACME } \\
\text { scholars) } \\
\text { Total Number }\end{array}$ & 118 & 77 & $65.3 \%$ \\
\hline $\begin{array}{l}\text { Non-Minority } \\
\text { Students } \\
\text { Total Number }\end{array}$ & 530 & 378 & $71.3 \%$ \\
\hline
\end{tabular}

Table IV. 2006-2007 Cohort by Enrollment Periods and Percent Retention in Engineering

\begin{tabular}{|l|l|}
\hline & $\begin{array}{l}\text { Enrollment } \\
\text { Period }\end{array}$ \\
\hline $\begin{array}{l}\text { 2007-2008 Cohort } \\
\text { First-time, Full-time } \\
\text { Students }\end{array}$ & $\begin{array}{l}\text { Fall } \\
\text { 2007-2008 }\end{array}$ \\
\hline $\begin{array}{l}\text { Block Grant NACME } \\
\text { Scholars } \\
\text { Total Number }\end{array}$ & 11 \\
\hline $\begin{array}{l}\text { Minority Students } \\
\text { (excluding NACME } \\
\text { scholars) } \\
\text { Total Number }\end{array}$ & 123 \\
\hline $\begin{array}{l}\text { Non-Minority Students } \\
\text { Total Number }\end{array}$ & 564 \\
\hline Table V. 2007-2008 Cohort by Enrollment Period in Engineering \\
\hline
\end{tabular}




\begin{tabular}{|l|l|l|l|}
\hline & \multicolumn{2}{|c|}{ Enrollment Periods } & \\
\hline $\begin{array}{l}\text { 2003-2004 Cohort } \\
\text { First-time, Full- } \\
\text { time Students }\end{array}$ & $\begin{array}{l}\text { Fall } \\
\text { 2003-2004 }\end{array}$ & $\begin{array}{l}\text { Fall } \\
\mathbf{2 0 0 7 - 2 0 0 8}\end{array}$ & $\begin{array}{l}\text { Retention } \\
\%\end{array}$ \\
\hline $\begin{array}{l}\text { Block Grant } \\
\text { NACME Scholars } \\
\text { Total Number }\end{array}$ & 21 & 16 & $76.2 \%$ \\
\hline $\begin{array}{l}\text { Minority Students } \\
\text { (excluding } \\
\text { NACME scholars) } \\
\text { Total Number }\end{array}$ & 147 & 83 & $56.5 \%$ \\
\hline $\begin{array}{l}\text { Non-Minority } \\
\text { Students } \\
\text { Total Number }\end{array}$ & 591 & 408 & $69.0 \%$ \\
\hline
\end{tabular}

Table VI. 2003-2004 Cohort by Enrollment Periods and Percent Retention at ASU.

\section{Student Evaluations of the Course}

The validity of an evaluation of a course by freshmen students who have just completed their first semester of college may be questioned. The students have very few college classes with which to compare. It is at least of interest to look at the evaluations of the NACME Academic Success Class over the five years of the course. The evaluations are quite consistent. During the first four years the course was team-taught by the Associate Director of Student Affairs and the first author. This year only the author taught the course. A very competent undergraduate student. who had worked with the students in the Summer MEP Program, assisted with the course and was the grader. The evaluations seemed to be consistent in spite of this change. See Table VII. One Fall 07 student rated the overall quality of the course and instruction as Poor. All other students rated the overall quality of the course as Good, Very Good, or Excellent.

\begin{tabular}{|l|l|l|l|l|l|}
\hline \multicolumn{2}{|l|}{ NACME ACADEMIC SUCCESS COURSE EVALUATION } \\
\hline $\begin{array}{l}\text { Very Good=5, Good=4, Fair=3, Poor=2, Not } \\
\text { applicable=1 }\end{array}$ & $\begin{array}{l}\text { Fall 03 } \\
(14 / 29) \\
48.28 \%\end{array}$ & $\begin{array}{l}\text { Fall 04 } \\
(21 / 23) \\
91.3 \%\end{array}$ & $\begin{array}{l}\text { Fall 05 } \\
(14 / 20) \\
70.0 \%\end{array}$ & $\begin{array}{l}\text { Fall 06 } \\
(17 / 21) \\
81.0 \%\end{array}$ & $\begin{array}{c}\text { Fall 07 } \\
68.75 \%\end{array}$ \\
\hline Part 1: Student Evaluation of Course & 4.31 & 4.04 & 3.88 & 4.13 & 3.96 \\
\hline $\begin{array}{l}\text { Part 2: Student Evaluation of } \\
\text { Instructor }\end{array}$ & 4.44 & 4.51 & 4.21 & 4.44 & 4.45 \\
\hline $\begin{array}{l}\text { Overall quality of the course and } \\
\text { instruction }\end{array}$ & 4.21 & 4.24 & 3.57 & 4.12 & 3.91 \\
\hline $\begin{array}{l}\text { How do you rate yourself as a student } \\
\text { in this course? }\end{array}$ & 4.21 & 4.10 & 4.21 & 4.12 & 4.09 \\
\hline
\end{tabular}

Table VII. NACME Academic Success Course Evaluation

At the end of the semester the NACME students were asked to write an essay on how the Freshman Success Course helped them in their first semester. The students were to include the 
five most important things that they learned during the semester and answer the following questions in detail within the essay:

- What aspect of the 4.0 Plan worked the best for you? What did not work?

- What are some important things that the text ${ }^{9}$ taught you?

- What did you learn from your peers in the class?

- Did you or are you going to achieve the goal you set for your first semester of getting a 4.0? Why or why not?

The essay was to be at least two pages long and no more than five pages, 12pt font, double spaced.

As a group, most of the students appreciated being introduced to the 4.0 Plan. One student wrote, "The 4.0 really helped me decide a plan for the first semester. It was the road that I needed to set me on the way for the future...." Several students admitted at first they did not believe that the 4.0 Plan could really work. "I believe that unconsciously I was a bit skeptical about the promise of the 4.0 Plan and therefore I did not follow it as well as I should have." Most of these doubters started using parts of the Plan during the semester and admitted that next semester they will try the whole plan right at the beginning of the semester. A couple of students flinched at the strictness of trying to follow a schedule. One student felt that he worked best just keeping notes each day of what had to be done and then do it. One student reported, "The 4.0 Plan is extremely helpful and seems very effective, but it is difficult to implement." Another student added, "I really appreciated the introduction of the 4.0 Plan, even though I was not able to maintain it nearly at all this semester. It helps to know that someone had cared enough to do a little bit of research into what helps to make a solid grade point average, and to know that it really was possible to maintain a 4.0 in my classes, despite how overwhelmingly hard they seemed."

The students varied on which parts of the 4.0 Plan were the most useful. The Bullet Point Reading of material before class was most often mentioned by the students as the most helpful. Utilizing professor office hours was mentioned by several of the students as very useful. Note taking and reviewing right after class was also mentioned as being effective. Based on the reading before class, taking notes and reviewing them, one student noticed that he felt confident of the material when it was time for the lab and that he "was one of the first ones to escape the computer lab. This made me feel proud of myself." Several students ended their essays with "I intend to employ the 4.0 Plan next semester..." One student wrote: "I intend to employ the 4.0 Plan next semester when I am able to start it from Day 1 of the semester instead of figuring out how it works halfway through the semester and playing catch-up to make up for it. I feel I will be much more successful next semester, and know better what I can expect of myself and college."

The students liked the textbook: "The book had a lot of great information." "The Engineering Student Survival Guide proved to be my most utilized source of information from this class." "The book taught me a lot. It told me that life and college life isn't all about studying and taking tests." "The book used in this introduction course covered all the situations that engineers have to overcome during college...However, the most important thing that this book taught me is that there are always ways to prevent the problems. Even if that problem still occurs, there is always a solution for it." "I despise that book but loved it at the same time... another thing I hated from this book is that it constantly tells us that we will most likely not succeed in engineering because 
of how hard it is, ... however, I loved the book because of its details and explanation on the pathway to graduation and the rest of the road after graduation." "When I was first given the book, I thought it was a joke. I really didn't understand the point of all the book assignments until I realized that there is some useful information in there. I wasn't taking the book work seriously at first, until it hit me, that I could actually apply this material to my life! The book really does a good job of actually relating to you personally." Two students mentioned that they learned about the "FE" exam in the textbook. "I found the book to easily be read and I would one hundred percent recommend the book to all students in the engineering discipline."

The students were asked to write about their peers in the class. One student wrote: "From my peers I learned the important facet of humans. Everyone was so different yet we are all motivated to be disciplined the same and go through the same struggles. Being in a class with all minorities, I identified with students when they spoke of their sub-wealthy childhood and some of their motivations matched mine." Another student said, "When looking back at the class I learned that a lot of my peers are struggling and struggle just as I do. One thing that I really enjoyed was the individual presentations. ..Even when the people that were from Phoenix stayed at ASU, (they) had such different stories and each one was so unique in its own way." "I feel my friends were really there for me in the class...It was really nice to be able to have friends by your side to support each other when it came to following the 4.0 Plan." "One of my favorite aspects from this course was to meet new people. The majority of my classmates were part of the Minority Engineering Program during the summer of 2007. Even though we were together for two weeks, during this course I found out things I did not know about them. The personal presentations allowed me to know certain events that have happened in their lives and understand them better." "From working with my peers in this class, I learned that we're probably going to be going through the same things throughout our 4 or 5 years here so it's best that we stick together." One student was delighted to find quite a bit of humor in individuals and in the class: "However, the most important lesson my peers taught me was that I was not alone in my struggles with the 4.0 plan or with school."

Experience with the course has shown that the most important part of the class is for the students to learn that they are not alone in their struggles. One student wrote an excellent paragraph on the importance of the peers in this class: "The students in the FSE 194 class acted almost like a support group for me. Watching my roommate and my neighbors constantly have fun and yet not worry about class, made me think I was the only student struggling in the program. Yet, every Wednesday, I was able to sit down with some of the brightest kids I know and discuss the problems we were having with our classes. The sheer knowledge that I was not the only student having problems and having stress made the situation much easier. Before the class met, I assumed that I was the only person having problems, and I used to get down on myself for not doing as well as everyone I met. But once I found out that others were going through similar situations, I felt much more comfortable with my situation."

Two students noted that teamwork in this class was a lot different than teamwork in high school. "In this class, I found everyone to be very hard-working too. This surprised me since back home I would have to do most of the work and carry other group members. Another lesson that I learned from them is to always rely on them." Another student wrote: "As far as this class, I learned a lot working with my peers. I had worked on group projects throughout high school, 
but working in groups in college is a complete different experience. In high school, working in a group for me would usually mean that I did all the research and then (would) tell everyone else what I needed them to do for the completion of the project. A complete turn around from high school was college. Now, working in a group means that we all do our individual research and meet and discuss thing(s) together as a real team." Hopefully these students will continue to be in good teams throughout college.

Only a few students said that they expected to get close to the grades that they had predicted. Several students said that getting a 3.25 or 3.5 so they could keep their scholarships was a good enough goal. Several students admitted that they had not done as well as they should have. In a couple of cases the student admitted to taking too many hours (all students were warned about this at the beginning of the semester, but most did not believe they had too many) in which one class pulled them down in the rest of the classes before they finally dropped the class. Most students observed that they had learned a lot during the semester and now knew what they needed to do in the next semester to raise their GPA. Most plans included starting with Bullet Point Reading and taking notes in class and going over them right after class.

Interestingly, several students did not take the course seriously until well into the semester. "Initially, I didn't think the Freshmen Success Course would help me at all here at Arizona State. I maintained the impression that it was a complete waste of my time for the majority of the semester, along with the majority of the class, and did not put as much into the course as I did my other courses." Another student admitted: "At first when I was in the class, I really thought I knew all I need to know. I was part of the Minority Engineering Program (MEP) Summer Bridge, and there I was taught a lot about a typical freshman year. I figured what more is there... what else could this class possibly teach me? As the semester continued I then began to realize that there was some useful information that I didn't know." This same student also wrote: "All-in-all, I feel the class benefits everyone in some way, shape, or form. Anyone who says otherwise would be lying. The class helps prepare students for a successful year by providing them with good study habits, resources and just some personal tips.....It showed me what I need to work on and showed me that I might have to change some of my study habits to succeed here in college."

One student was at first very disappointed: "When I was first told that I received another scholarship for Minorities in Engineering I was really looking forward to the class that was going to come with it. However, the class was a lot different from what I initially thought. I was telling myself that this was going to be a class that would give me time to do homework or get tutoring if I needed. However, this was not the case. Instead the class ended up helping more than with just homework. This class helped me learn how to succeed as a college student....I think the most important thing that I learned this semester is that staying on top of your work is the key to success. Using some parts of the 4.0 plan, I was able to keep up with my studying and stay caught up and at the same time I had a great social life and was able to go out and have fun. Another thing I learned is getting involved with on-campus activities give students huge advantages out in the work force. This gives students the skills they need outside the classroom to succeed." 
Several of the students expressed their appreciation to the instructor and the student assistant as in "I just really want to thank Callie and Dr. A-R for all the work, time and effort they put into the class. I really hope this continues to benefit others, just as it has me."

Many students confessed that they did not do as well as they could have. So, how did the students do? The next section tells the story.

\section{First Semester GPA Results}

The students are urged to follow the 4.0 Plan from the beginning of their engineering program. The purpose for this is to give the students a plan that enables them to learn well so the students will: feel more confident about succeeding in engineering, begin to build a strong GPA foundation, more likely stay in engineering and graduate, have a good academic foundation as they proceed to higher level classes, and reduce stress with a good time management Plan. This class appeared to not take an academic time management plan as seriously as preceding classes. Table VIII shows how they compared after one semester. In the Fall 07 class, there were two students who were not minority students. Of the 14 minority students in the class, 9 were NACME students (2 more became NACME students in the spring semester), and three minority students were in the class either because they received an MEP Scholarship from the summer program or received $\$ 100$ by MEP for taking the course. One of the minority students who took the class would have been awarded a NACME scholarship but had no unmet financial need due to other scholarships the student had already received. Of the 11 NACME students, four had a GPA below 3.0. In looking at Table VIII recall that the first two cohorts did not know about the 4.0 Plan during their first semester.

\begin{tabular}{|l|c|c|c|c|c|}
\hline Cohort & $\mathrm{n}$ & GPA avg. & $<2.0$ & $<2.6$ & $>3.0$ \\
\hline I. Fall 03 (all min.) & 21 & 3.04 & $2(9.5 \%)$ & $5(23.8 \%)$ & $15(71.4 \%)$ \\
\hline II Fall 04 (all) & 14 & 2.85 & $0(0.0 \%)$ & $5(35.7 \%)$ & $5(35.7 \%)$ \\
\hline Fall 04 (min. only) & 10 & 2.73 & $0(0.0 \%)$ & $4(40.0 \%)$ & $2(20.0 \%)$ \\
\hline III Fall 05 (all) & 18 & 3.63 & $0(0.0 \%)$ & $0(0.0 \%)$ & $17(94.4 \%)$ \\
\hline Fall 05 (min. only) & 15 & 3.54 & $0(0.0 \%)$ & $0(0.0 \%)$ & $14(93.3 \%)$ \\
\hline IV Fall 06 (all) & 20 & 3.23 & $2(10.0 \%)$ & $2(10.0 \%)$ & $14(70.0 \%)$ \\
\hline Fall 06 (min. only) & 17 & 3.17 & $2(11.8 \%)$ & $2(11.8 \%)$ & $11(64.7 \%)$ \\
\hline V Fall 07 (all) & 16 & 3.12 & $2(12.5 \%)$ & $4(25.0 \%)$ & $11(68.75 \%)$ \\
\hline Fall 07 (min. only) & 14 & 3.08 & $2(14.3 \%)$ & $4(28.6 \%)$ & $9(64.3 \%)$ \\
\hline
\end{tabular}

Table VIII. GPAs at End of First Semester for Freshmen Students Completing the Academic Success Class

This Academic Success Class actually performed about the same as the first cohort which did not have the 4.0 Plan. The percentage of students receiving over a 3.0 is about the same as that for Fall 06. Of the 11 Fall 07 NACME students, 1 had a GPA less than 2.0, 3 had a GPA below 2.6, and 4 had a GPA below 3.0. Five of the 7 NACME students with at least a 3.0 GPA had a GPA of over 3.5. The top three NACME students had GPAs of 4.08, 3.98 and 3.87. Two of the students with low grades tried to carry too many hours.

An interesting observation is that through the first three cohorts of the Academic Success Class the students all seem committed to the class and earned an A. In the fourth cohort one student chose not to complete the assignments and received a B in the course. In this fifth cohort, one student received an A- and two students received C's for their work in the class. All three of 
these students had a semester GPA below a 3.0 and the two C students earned semester GPAs less than 2.5. Therefore, in the future, we should conclude that if students are not diligent in their assignments with a class in which they can earn an A with some effort, then it is likely they may not be diligent in their other classes and some personal counseling may be in order. At a minimum such a student should be asked in private how they are doing in their other classes and given additional mentoring, if possible.

\section{Summary and Conclusion}

Some parts of the first cohort program still remain strong and are valued by the students. These include the individual student presentations and the group project. Each year a little more structure has been given to the students on what is expected for the project and the instructors have received fewer complaints about the project process. As seen in the student comments, some were pleasantly surprised that they did not have to carry most of the project by themselves. The individual presentations have always been popular. The student giving the presentation gains confidence in the process and the students learn more about their peers, even if they spent two weeks together in the summer in the MEP Summer Bridge Program.

The textbook has been changed from the original one used for the course and the students all seemed to find some or high value to the book. The book is provided to them without cost. Several students commented that they would keep the book handy as a reference in the coming years since it seemed to cover almost all situations in which students might find themselves.

The student panel of officers from AISES, NSBE, SHPE, and SWE was well received and several students became quite involved with a student organization to the point that two of the Fall 07 freshmen students attended the national meeting of the student organization. Both of these students felt that the national meeting strengthened their commitment to be an engineer, however, the time away from classes put more stress on completing the semester well.

In the early cohorts all of the video series of "When There's a Will, There's An 'A""18 were shown with mixed evaluations. Just three of the series were shown in Fall 07 as reinforcement for the basics taught in the 4.0 Plan.

From the beginning of the course, graduate school has been presented to the students. A good reason for having a GPA at least 3.0 is the better opportunity to get into graduate school. During the second semester of the program on, engineers from industry with graduate degrees are brought in to speak to the students. These meetings have always been well received. Two of the three graduates of the NACME program have gone on to graduate school. Other students near graduation are applying to graduate schools.

The essay was a new assignment and seemed to be well received by the students (they received quite a few points for it) and made for interesting and fun feeding for the instructors. The essays gave the students a good format for evaluating the course and gave more detailed feedback to the instructors about the course and how the students evaluated it. This exercise will be continued as a part of the NACME program. 
The challenge remains on how to motivate a group of freshmen at the beginning of their first semester into understanding that they will need to organize their lives and will not be able to cram in material the night before an exam and still pull an A as they did in high school. The students are told this, but most do not believe it. Although the semester average GPA for this group was lower than desired, it is believed that without the Academic Success Class and the 4.0 Plan, the grades would have been considerably lower.

The program has been considered a success. The engineering retention rate of the NACME minority students after four years $(47.6 \%)$ is higher than that of non-minority students $(40.8 \%)$. In addition, the engineering retention rate of the four year NACME minority students is much higher (close to double) than that of minority students not in the NACME program (27.2\%), including minority students who attended the Minority Summer Bridge Program. In addition, after four years, the ASU retention of the NACME students is $76.2 \%$, while the ASU retention of non-minority students is $69 \%$ and the ASU retention of minority students not in the NACME program is $56.5 \%$. Contingent on future funding, the NACME Academic Scholarship Program will be continued.

\section{Bibliography}

1. Youngman, J.A., and Egelhoff, C.J., "Best practices in Recruiting and Persistence of Underrepresented Minorities in Engineering: A 2002 Snapshot," Proceedings: Frontiers in Education, $30^{\text {th }}$ Annual Conference, Kansas City, Missouri, October 2000, Session F2D, pp. F2D-11-F2D-16.

2. Reyes, M. A., Gotes, M. A., McNeill, B., and Anderson-Rowland, M. R., "MEP Summer Bridge Program: A Model Curriculum Project," ASEE Annual Conference Proceedings, Charlotte, North Carolina, June 1999, CD Rom, 8 pages.

3. McGee, M.M. and Fentiman, A.W., "Components of a Year-Long Bridge Program for Minority Engineering Students," Proceedings of the 2004 American Society for Engineering Education Annual Conference, Salt Lake City, June 2002, 5 pages.

4. Ohland, M., Zhang, G., Foreman, F., and Haynes, F., "The Engineering Concepts Institute: The Foundation of a Comprehensive Minority Student Development Program at the FAMA-FSU College of Engineering," Proceedings: Frontiers in Education, $30^{\text {th }}$ Annual Conference, Kansas City, Missouri, October 2000, pp. F1F-17F1F-20.

5. Catalano, G.D., and Catalano, K., "The Binghamton Success Program: Institutionalizing a Minority Engineering Program," Proceedings: Frontiers in Education, $34^{\text {th }}$ Annual Conference, Savannah, GA, November 2004, pp. S1G-1-S1G-3.

6. Monte, A.E. and Hein, G. L., "An Innovative Program to Support Undergraduate Engineering Students from Underrepresented Groups," Proceedings of the 2004 American Society for Engineering Education Annual Conference, Salt Lake City, UT, June 2004, 12 pages.

7. Anderson-Rowland, M.R. and Newell, D.C., "Evaluation a NACME Academic Scholarship Program," $35^{\text {th }}$ ASEE/IEEE Frontiers in Education Conference Proceedings, Indianapolis, Indiana, October 2005, 7 pages.

8. Anderson-Rowland, M.R. and Newell, D., "Lessons Learned in A successful Underrepresented Minority Retention Program," Proceedings of the 2005 American Society for Engineering Education Annual Conference, Portland, Oregon, July 2005, 10 pages.

9. Anderson-Rowland, M.R. and Newell, D., "Retaining Underrepresented Minority Freshmen in Engineering: A Two-Credit Class," Proceedings of the 2004 American Society for Engineering Education Annual Conference, Salt Lake City, July 2004, 8 pages.

10. Anderson-Rowland, M.R. and Newell, D.C., "Improving a NACME Class with an Emphasis on Detailed Time Management", Proceedings of the 2006 American Society for Engineering Education Annual Conference, Chicago, Illinois, July 2006, 12 pages.

11. Anderson-Rowland, M.R. and Newell, D.C., "The Blurring of Academic, Cultural, and Social Borders for Minority Engineering Students," $36^{\text {th }}$ ASEE/IEEE Frontiers in Education Conference Proceedings, San Diego, 
CA, October 2006, 7 pages.

12. Anderson-Rowland, M.R., "A Comparison of the Academic Achievements and Retention Rates of Women and Men Engineering and Computer Science Students in an Academic Scholarship Program Designed for Underrepresented Minority Students," Proceedings of the WEPAN Conference, 2007, Orlando, Florida, June 2007, 11 pages.

13. Anderson, M.R. and Newell, D.C., "A Three Year Evaluation of a NACME Program," Proceedings of the 2007 American Society for Engineering Education Annual Conference, Honolulu, Hawaii, July 2007, 8 pages.

14. Anderson-Rowland, M.R. and Culley, P.I., "Helping Lower Division Engineering Students Develop a Good Resume", Proceedings of the 2007 American Society for Engineering Education Annual Conference, Honolulu, Hawaii, July 2007, 9 pages.

15. Anderson-Rowland, M.R. and Rowland, J.R., "The Correlation between GPA and Percent Effort on the Guaranteed 4.0 Plan," 37 ${ }^{\text {th h }}$ ASEE/IEEE Frontiers in Education Conference Proceedings, Milwaukee, WI, October 2007, 9 pages.

16. Johnson, D.O. and Chen, Y.C., Guaranteed 4.0, JCYC Studio, Dallas, Texas, 2004.

17. Donaldson, K., The Engineering Student Survival Guide, Second Edition, McGraw-Hill Higher Education, New York City, New York, 2002.

18. "Where There's A Will There's an 'A'," @ Better Grades Seminars, LLC, SL2276.

19. Anderson-Rowland, M.R., "Evaluation of a Program to Encourage Underrepresented Minority and Women Students to Become Interested in Research and to Attain Graduate Degrees," Proceedings of the 2006 WEPAN Conference, Pittsburgh, PA, June 2006, 13 pages, CD-ROM. 